\title{
Tyrosine kinase inhibitor CEP-701 blocks the NTRK1/NGF receptor and limits the invasive capability of prostate cancer cells in vitro
}

\author{
CLAUDIO FESTUCCIA $^{1}$, PAOLA MUZI ${ }^{1}$, GIOVANNI LUCA GRAVINA ${ }^{2}$, DANILO MILLIMAGGI ${ }^{1}$, \\ SILVIA SPECA ${ }^{1}$, VINCENZA DOLO ${ }^{1}$, ENRICO RICEVUTO ${ }^{1}$, CARLO VICENTINI $^{2}$ and MAURO BOLOGNA ${ }^{1,3}$ \\ Departments of ${ }^{1}$ Experimental Medicine, ${ }^{2}$ Surgery, and ${ }^{3}$ Basic and Applied Biology, \\ University of L'Aquila, I-67100 L'Aquila, Italy
}

Received April 14, 2006; Accepted May 29, 2006

\begin{abstract}
In the prostate, cellular growth and differentiation are finely regulated by a complex interaction between stromal and epithelial cells under the control of both autocrine and paracrine regulatory factors such as the nerve growth factor (NGF). However, the role of NGF and its receptors including the high-affinity p-140 TrkA and the low-affinity p75 NTR receptors remains controversial. Moreover prostate tissues stored other neutrophins such as NT3, NT4 and brain derived neutrophic factor (BDNF) as well as the corresponding receptors (NTRs). Different members of NTRs are expressed during prostate cancer ( $\mathrm{PCa}$ ) progression, suggesting their involvement in cell proliferation, anoikis protection and malignancy. Therefore, we analyzed the expression of NTRs including NTRK1 (TrkA), NTRK2 (TrkB), NTRK3 (TrkC) and p75 NGFR in a panel of 7 well-characterized PCa cell lines and 12 cell derivatives from PC3 (4), DU145 (2), CWR22R (4) and LnCap (2) cell lines possessing different proliferative/ invasive capabilities. We evaluated also the role of NGF, BDNF and NT3 in the modulation of cell migration and invasion and, finally, the effects of a pan Trk inhibitor, CEP-701 which has been included in some clinical trials for the treatment of PCa. We observed the following: i) TrkA and TrkB expression was significantly higher in AR-negative compared to ARpositive cells; ii) TrkA and TrkB expression was related to the invasive capacity/malignancy of PCa cells; iii) p75 NGFR could be considered a tumor suppressor gene which is present at high levels only in AR-positive cells; and iv) that NGF and BDNF (targeting TrkA/p75 NTR and TrKB, respectively) induced cell migration and this was inhibited by the CEP-701
\end{abstract}

Correspondence to: Dr Claudio Festuccia, Dipartimento di Medicina Sperimentale, Cattedra di Patologia Generale, Università dell'Aquila, Via Vetoio, Coppito 2, I-67100 L'Aquila, Italy

E-mail: festucci@univaq.it

Key words: neutrophin receptors, prostate cancer chemotherapy, CEP-701 treatment. In conclusion, the malignancy of $\mathrm{PCa}$ seems to be accompanied by increased TrkA and TrkB signaling (with a reduction of p75 NGFR expression) and CEP-701 could be used to reduce the metastasis formation in advanced PCa. CEP-701 is a trademark of Cephalon Inc., West Chester, PA, USA.

\section{Introduction}

The neutrotrophin (NT) family of growth factors, NGF, BDNF, NT-3, NT-4/5, and their tyrosine kinase neutrophin receptors (Trks A, B, C and the low-affinity NGF receptor, p75 ${ }^{\text {NGFR }}$ ) have been implicated in the paracrine growth regulation of a number of neuronal and non-neuronal tumor types including prostate epithelium (1-3). Each NT binds to a specific Trk receptor: TrkA (NTRK1) binds specifically to NGF, TrkB binds to both BDNF and NT-4/5, and TrkC binds primarily to NT-3. However, NT-3 can bind and activate TrkA and TrkB as well. All NTs bind with various affinities to p75 ${ }^{\text {NGFR }}$, a receptor implicated in the regulation of neuronal cell survival, and in the modulation of NT affinity to the various trk receptor subtypes (reviewed in ref. 4). Although NTs aid in the development and maintenance of the adult nervous system, NTs have also been shown to increase tumor invasiveness, enhance clonal growth, and cause changes in cell morphology in a variety of non-neuronal cell types including Wilms' tumor, melanoma, lung, pancreatic, prostatic, medullary thyroid carcinoma and breast cancer (5-13). Normal prostatic tissue contains substantial levels of nerve growth factor (NGF), which is produced in a paracrine manner by stromal cells whereas epithelial cells express primarily trkA and p75 NTR. While the NGF/trkA/p75 NTR axis is present in the normal prostate, normal prostatic epithelial cells do not depend on this axis for their survival (11). In prostatic carcinoma (PCa) an autocrine loop involving NGF and TrkA is responsible for tumor progression (12-15), and tumor growth can be blocked by NTRK1 kinase inhibitors (14). Specifically, a) both primary and metastatic PCa as well as established PCa cell lines express trkA $(12,16)$; b) Djakiew et al (17) have demonstrated that an NGF-like protein, secreted from a human stromal cell line, stimulates the growth of a human prostate cancer cell line (TSU-Pr1), now referred to as T24 bladder carcinoma 
cell derivative (18); an effect which an anti-NGF antibody completely blocked; and c) NGF and NGF-like proteins appear to increase the motility and invasiveness of prostate cancer cell lines (15-17). Following NGF binding, NTRK1 undergoes dimerization and autophosphorylation of five tyrosine residues which culminates in the induction of genes mediating NGF effects on proliferation, differentiation and apoptosis. TrkB is a receptor tyrosine kinase that has brainderived neurotrophic factor as one of its primary ligands. It plays an essential role in the development and function of the neuronal system, including promotion of neuronal survival (19). It has been shown that TrkB protects cells against anoikis, in different epithelial cell lines. The prevalence of TrkB elevation in human cancer has prompted interest in this receptor as a therapeutic target. However, whereas we have provided evidence that TrkB overexpression is sufficient to drive tumorigenesis, invasion, and metastasis in experimental models, an important question remains as to whether TrkB activity is essential to maintain these malignant properties in human tumors. Also TrkC has been related to malignacy of some tumors due to its capabilities to activate the secretion and activation of proteases such as heparanase (20). p75 NGFR has been associated to prostate normal epithelium whereas its expression is decreased in malignant $\mathrm{PCa}(4,12-15)$. It has been shown that a pan-Trk inhibitor CEP-751 and its $O$-desmethyl metabolite, CEP-701 treatment of different models of human and rodent $\mathrm{PCa}$ inhibited the in vivo growth in all of the prostatic cancer sublines tested, independent of their state of differentiation, androgen sensitivity, metastatic ability, or growth rate $(13,14,21)$. Thus, considering the role of NT and NTR in prostate progression we addressed their expression and interactions in human PCa cell lines and evaluated the role of the inhibition of the Trk-mediated signaling transduction pathways by CEP-701 for the control of invasion capabilities of PCa cells.

\section{Materials and methods}

Reagents. All the materials for tissue cultures were purchased from Hyclone (Cramlington, NE). Plasticware was obtained from Nunc (Roskilde, Denmark). Reagents, when not otherwise specified, were purchased from Sigma Chemicals (St. Louis, MO, USA). Antibodies against AR, Ki67, TrkA, TrkB, TrkC and p75 NTR as well as against their phosphorylated forms and HRP-, FITC- and HRP-conjugated antibodies were purchased from Santa Cruz (Santa Cruz, CA, USA). CEP-701 was kindly provided by Cephalon Inc., West Chester, PA, USA.

Cell lines. We used a panel of 7 cell lines and 12 cell derivates: ND1 (22), LnCaP (23), 22rv1 (24) and CWR22R strains derived in our laboratory from three xenografted CWR22 Relapsed tumors (2152, 2274 and 2524, for which in vitro characterization was in preparation) were AR positive whereas PC3 (25), DU145 (26) and ALVA31 (27) cells were AR negative. DU145 and PC3 cells were transfected with the wildtype human androgen receptor or with a control neomycinresistant plasmid DNA [DU-AR, (28), PC3-AR (29)]. LnCaP, PC3 and DU145 cell lines were originally obtained from American Tissue Culture Collection (ATCC, Rockville, MD). ND1 cells were kindly provided by Dr R. Dahiya and ALVA31 were kindly provided by Dr B.A. Roos. Cells were cultured in DMEM supplemented with $10 \%$ FCS. Stably transfected cells were maintained in the presence of geneticin, repeatedly grown at low density (using different cell dilutions) and then screened. PC3 and $\mathrm{LnCaP}$ cells were compared to the cell derivatives, PCM-pro5, PC3M-Ln4, LnCaP-pro4 and LnCaPLn4, obtained from Dr Pattaway [M.D. Anderson Cancer Center, Houston, TX, USA (30)] and and with some cell derivative originates in our laboratory (PC3-Ly, a lymphnodal metastases of PC3 obtained after intraventricular injection (31) and PC3-TKIR, a Gefitinib-resistant PC3 cell line (unpublished data).

Immunocytochemical analysis of Trk expression. Cells were cultured in 5\% FCS DMEM. Quantification of positive cells was performed by flow cytometric analysis (FACScan; Becton Dickinson, Mountain View, CA, USA). Cells were trypsinised, centrifuged and left at $37^{\circ} \mathrm{C}$ for $1 \mathrm{~h}$ in DMEM/10\% FCS in polypropylene tubes in order to reconstitute cellular external membrane. Cells were washed in saline buffer and $1 \times 10^{6}$ cells were fixed in a $3.7 \%$ paraformaldehyde buffered solution, washed twice and then treated with $\sim 10 \mu \mathrm{g} / \mathrm{ml}$ of primary antibodies. After $1 \mathrm{~h}$ at $4^{\circ} \mathrm{C}$ cells were washed twice in PBS and FITC-anti-rabbit and anti-mouse secondary antibodies $(\sim 1 \mu \mathrm{g} / \mathrm{ml})$ were added to the fixed cells. After $30 \mathrm{~min}$ of incubation at $4^{\circ} \mathrm{C}$, cells were washed twice and resuspended in PBS at $1 \times 10^{6}$ cells $/ \mathrm{ml}$ before analysis.

Migration and invasion assay. Cell migration was quantified by the number of cells that migrated directionally through a gelatin-coated $8-\mu \mathrm{m}$-pore polyvinyl pyrrolidone-free polycarbonate filter (Poretics, Livermore, CA, USA) in Boyden Chambers. Filters were plated into contact with the lower chamber containing $200 \mu \mathrm{l}$ of serum-free medium or $10 \%$ FCS containing medium (control). Briefly, cells $\left(1 \times 10^{6}\right.$ cells/ $\mathrm{ml}$ ) were resuspended in serum-free DMEM and were either untreated or pretreated at room temperature with inhibitors (15 min) or antibodies (45 min). Recombinant human EGF (Becton Dickinson) was diluted to the indicated concentrations and added to the lower wells. Cells were then added to the top of each chamber and allowed to migrate through coated filters for $6 \mathrm{~h}$. Non-migrated cells on the upper membrane surface were removed with a cotton swab, and the migratory cells attached on the lower membrane surfaces were stained with Diff-Quik (Baxer Scientific, McGaw Park, IL, USA). Cells were counted at a magnification x400 in standard microscopy and the mean number of cells per field in 5 random fields was recorded. Triplicate filters were used and the experiments were repeated 3 times. Invasion assay was performed as above except for the presence of filters coated with $25 \mu \mathrm{g} / \mathrm{ml}$ of matrigel.

Statistical analyses. Data are expressed as the mean \pm SEM of at least three independent experiments. Statistical analysis was performed using an unpaired Student's t-test.

\section{Results}

Neutrophin receptor expression. We tried a possible correlation with Trk expression and androgen dependence/sensitivity 
Table I. Correlation between neutrophin receptor expression and androgen receptor in PCa cell lines by FACS analysis. ${ }^{a}$

\begin{tabular}{|c|c|c|c|c|c|}
\hline Cell line & $\mathrm{AR}$ & TrkA & TrkB & TrkC & P75 NTR \\
\hline PC3 & - & 5.0 & 3.7 & 2.2 & 0.5 \\
\hline PC3 neo & - & 5.0 & 3.4 & 3.0 & 0.5 \\
\hline ALVA31 & - & 7.0 & 5.0 & 4.5 & 1.0 \\
\hline DU145 & - & 9.5 & 6.9 & 1.0 & 0.5 \\
\hline $\begin{array}{l}\text { DU145 } \\
\text { pcDNA }\end{array}$ & - & 9.4 & 7.1 & 1.0 & 0.5 \\
\hline Mean & & $7.2 \pm 2.2$ & $5.2 \pm 1.7$ & $2.3 \pm 1.5$ & $0.6 \pm 0.7$ \\
\hline DU-AR & + & 6.1 & 5.1 & 1.0 & 2.0 \\
\hline PC-AR & + & 3.0 & 3.0 & 1.5 & 1.5 \\
\hline $\begin{array}{l}\text { CWR22R } \\
2152\end{array}$ & + & 4.0 & 2.9 & 2.0 & 1.0 \\
\hline $\begin{array}{l}\text { CWR22R } \\
2272\end{array}$ & + & 3.0 & 3.1 & 2.0 & 0.5 \\
\hline $\begin{array}{l}\text { CWR22R } \\
2274\end{array}$ & + & 5.0 & 3.1 & 2.5 & 1.5 \\
\hline $\begin{array}{l}\text { CWR22R } \\
2524\end{array}$ & + & 7.0 & 2.9 & 2.0 & 3.0 \\
\hline $22 \mathrm{rv} 1$ & + & 6.5 & 2.9 & 3.0 & 1.5 \\
\hline ND1 & + & 4.0 & 2.5 & 1.5 & 2.0 \\
\hline $\mathrm{LnCaP}$ & + & 3.2 & 1.0 & 0.5 & 0.5 \\
\hline Mean \pm SD & & $4.8 \pm 1.5$ & $2.9 \pm 1.1$ & $1.7 \pm 0.8$ & $1.6 \pm 0.2$ \\
\hline
\end{tabular}

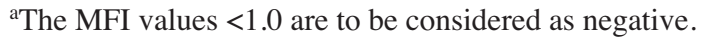

considering AR expression as marker. Thus we compared by FACS analysis the expression of the neutrophin receptors, in a battery of 7 well-characterized PCa cell lines and 12 cell line derivatives from PC3 (5), DU145 (2), CWR22R (3) and LnCap (2) cell lines, with the AR expression (Table I). We found the following: a) TrkA was expressed at intermediate/ high levels in approximately all PCa cell lines. In addition the TrkA expression was statistically higher in AR-negative when compared to AR-positive cells $(p=0.046)$. In addition DU145 cells transfected with the human AR gene presented significantly lower levels of TrkA compared to parental cells or with cells transfected with the empty vector. b) TrkB was expressed at low/intermediate levels in 16/19 PCa cells $(84.2 \%)$, whereas $3 / 19$ cells $(15.8 \%)$ were considered as negative. TrkB expression was statistically higher in ARnegative when compared to AR-positive cells $(\mathrm{p}=0.014)$ and DU-AR and PC3-AR presented lower levels of TrkB when compared with those presented by parental cells or by cells transfected with the empty vector. c) TrkC expression was expressed at intermediate/high (MFI>4.0) levels in $3 / 19$ $(15.8 \%)$ PCa cells, at low levels $(1.0<\mathrm{MFI}<4.0)$ in $10 / 19$ $(52.6 \%)$ whereas $6 / 19(31.6 \%)$ were considered as negative. TrkC expression was not statistically different in AR-negative
Table II. Neutrophin expression in derivatives from PC3 and LnCaP cell lines by FACS analysis.

\begin{tabular}{lccccc}
\hline Cell line & AR & TrkA & TrkB & TrkC & P75 NTR \\
\hline PC3 & - & 5.0 & 3.7 & 2.2 & 0.5 \\
PC3-pro5 & - & 4.5 & 2.8 & 2.5 & 0.5 \\
PC3-Ln4 & - & 6.0 & 5.0 & 3.2 & 0.5 \\
PC3-Ly & - & 6.0 & 4.8 & 2.8 & 0.5 \\
PC3-TKi-R & - & 7.5 & 2.0 & 3.0 & 0.5 \\
LnCaP & + & 3.2 & 1.0 & 0.5 & 0.5 \\
PC3-pro4 & + & 2.0 & 1.0 & 1.5 & 0.5 \\
LnCaP-ln4 & + & 5.2 & 5.0 & 0.5 & 0.5 \\
\hline
\end{tabular}

when compared to AR-positive cells; d) p75 NTR expression was expressed at low/very low levels, and 12/19 (63.2) cell lines were considered as negative $(\mathrm{MFI}<1.0)$. In addition the p75 NTR expression was statistically lower in AR-negative when compared to AR-positive cells $(\mathrm{p}=0.013)$.

Expression of neutrophin receptors and PCa malignancy in vivo and in vitro. We tried to find a possible relationship between Trk expression and malignancy of cells. For this purpose we made the following comparisons: i) PC3 cell line with its more malignant variants, PC3M-pro5; PC3M-Ln4, PC3-Ly and PC3-TKIR, obtained after repeated in vivo orthotopic injections (PC3M-pro5 and PC3M-Ln4) by Pettaway and coworkers and intracardiac injections (PC3-Ly) or after in vitro selction using an anti-EGFR-TK inhibitor, Gefitinib (PC3-TKIR); ii) LnCaP cell line with its more malignant variants, $\mathrm{LnCaP}-$ pro4 and $\mathrm{LnCaP}-\mathrm{Ln} 4$ obtained after repeated in vivo orthotopic injections by Pattaway and coworkers; and iii) among CWR22R variants obtained in our laboratory from xenograft strains CWR22R possessing different in vivo growth capacity. The results are summarized in Table II.

We found the following: a) the expression of TrkA was higher in more malignant PC3 derivatives especially in Gefitinib-resistant PC3 cells suggesting that the progression at more advanced tumors can be also associated to the resistance to different chemotherapeutic agents such as EGFR-TKI (unpublised data). No differences were observed for TrkB and p75 NTR whereas TrkC was increased in all derivates. b) LnCaP variants expressed significantly higher levels of TrkA reforcing the data suggested in point 1 . No differences were observed for TrkB, TrkC and p75 NTR. c) The more proliferating 2152 and 2524 variants possessed higher levels of TrkA and TrkB. No differences were observed for TrkC and p75 NTR.

Expression of neutrophins in PCa cell lines. We analyzed by immunocytochemistry the production of NGF, NT3, NT4/5 and BDNF in cells grown on chamber slides without any proliferative supplement. All PCa cell lines were tested; their derivatives produced neutrophins, except for the $\mathrm{LnCaP}$ cell line and its cell derivatives (Table III). 
Table III. Neutrophin expression in PCa cell lines by immunocytochemical analysis.

\begin{tabular}{lcccc}
\hline Cell line & NGF & NT4 & NT3 & BDNF \\
\hline PC3 & ++ & + & + & + \\
ALVA31 & ++ & + & + & ++ \\
PC3 neo & ++ & + & + & + \\
DU145 & + & ++ & - & + \\
DU145 pcDNA & + & ++ & - & + \\
DU-AR & + & ++ & - & + \\
PC-AR & ++ & + & \pm & \pm \\
CWR22R 2152 & ++ & + & + & + \\
CWR22R 2272 & + & + & + & + \\
CWR22R 2274 & ++ & + & + & ++ \\
CWR22R 2524 & ++ & + & ++ & + \\
22rv1 & ++ & + & ++ & + \\
ND1 & + & + & - & - \\
LnCaP & - & + & - & - \\
\hline
\end{tabular}

-, negative expression; +, low expression; ++, high expression; and \pm , very low expression.
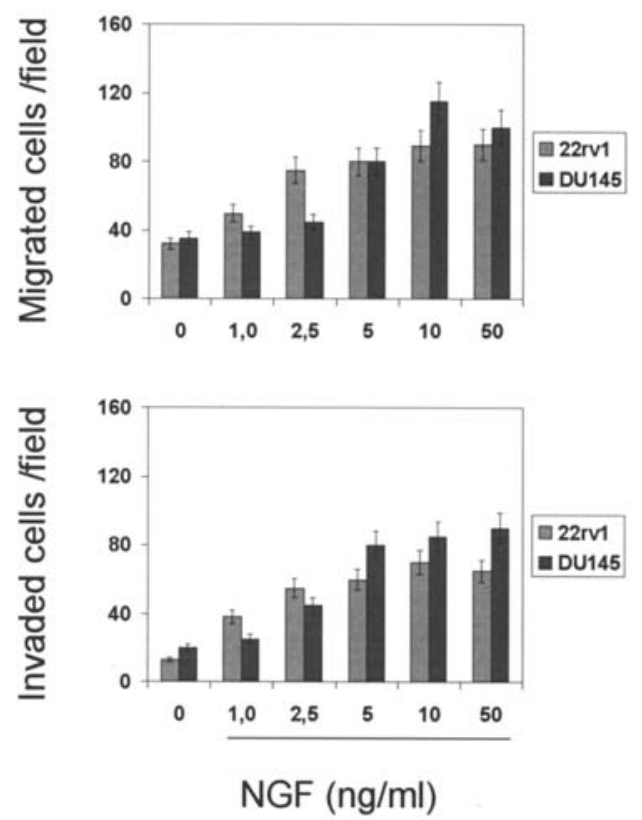

Figure 1. Chemotaxis and chemoinvasion of 22rv1 and DU145 using NGF as a chemoattracting agent. This is a representative dose-dependent experiment. Each value is the mean of triplicate counts $\pm \mathrm{SE}$. $\mathrm{P}<0.001$ after $2.5 \mathrm{ng} / \mathrm{ml}$ NGF.

Neutrophins are able to modulate the migratory and invasive capabilities of PCa cells. Next, we evaluated the modulation of migratory and invasive capabilities of PCa cells in boyden chamber assay with NGF, BDNF and NT3 used as chemoattracting agents.
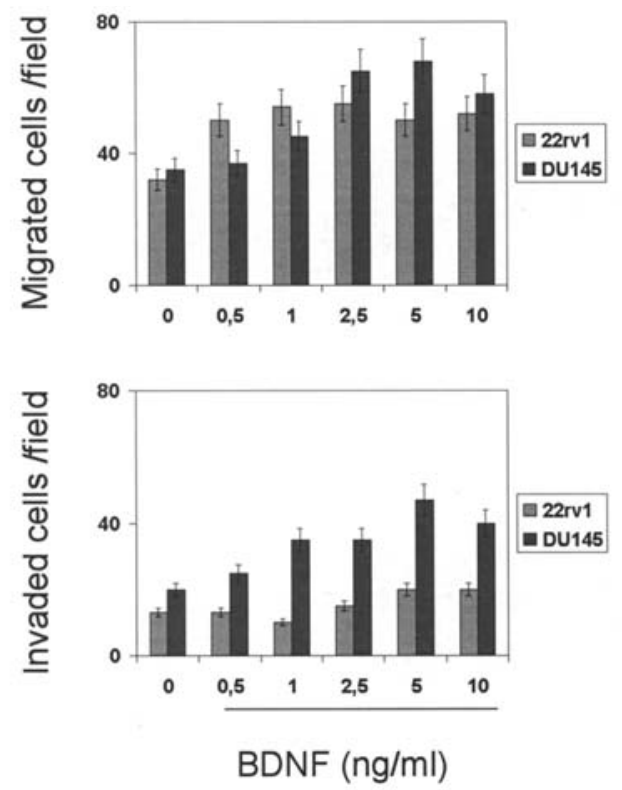

Figure 2. Chemotaxis and chemoinvasion of 22rv1 and DU145 using BDNF as a chemoattracting agent. This is a representative dose-dependent experiment. Each value is the mean of triplicate counts $\pm \mathrm{SE}$. $\mathrm{P}<0.001$ after $2.5 \mathrm{ng} / \mathrm{ml}$ BDNF.

Effects of NGF. In Fig. 1 we show the migratory and invasive dose-response effects of NGF (targeting TrkA/p75 NTR) in 22rv1 and DU145 cells. NGF was able to induce a chemotactic response and matrigel invasion with a maximal effect between 5-50 ng/ml. NGF (10 ng/ml) has been used to compare its effect in all $\mathrm{PCa}$ cell lines. We observed that NGF induced chemotaxis and matrigel invasion to a different extent in both AR-negative and AR-positive cells (Table IV). We found the following: i) as expected AR-positive cells presented a lower migratory capability than AR-negative cells ( $\mathrm{p}=0.024)$; ii) NGF-induced cell migration was statistically higher in AR-negative than in AR-positive cells ( $\mathrm{p}=0.038)$, with a similar fold increase (2.5); iii) as expected AR-positive presented a lower invasive capability than AR-negative cells $(\mathrm{p}=0.001)$ with statistically lower invasion indices $(\mathrm{p}=0.005)$; iv) NGF-induced matrigel invasion was higher in AR-negative than in AR-positive cells ( $\mathrm{p}=0.008)$ but with the same increase of $\sim 4$-fold; v) the invasion indices were statistically higher in AR-negative than in AR-positive cells $(\mathrm{p}=020)$ but with the same increase of $\sim 1.5$-fold; however the increment of NGFinduced invasion index was statistically significant only in AR-negative cells $(\mathrm{p}<0.001)$; and vi) the NGF-induced cell invasion (analyzing the invasion indices) was highly related with TrkA expression, with a correlation coefficient of 0.806 ( $\mathrm{p}=007)$, but not with $\mathrm{p} 75$ NTR expression.

Effects of BDNF. In Fig. 2 we show the migratory and invasive dose-response effects of BDNF (targeting TrkB) in 22rv1 and DU145 cells. BDNF is able to induce chemotactic response and matrigel invasion with a maximal effect between 5 and $10 \mathrm{ng} / \mathrm{ml}$. The effect of BDNF (10 ng/ml) has been compared in all PCa cell lines (Table IV). We found the following: i) BDNF-induced cell migration was higher but not statistically higher in AR-negative than in AR-positive cells with a similar increase of $\sim 1.5$ fold; ii) BDNF-induced 
Table IV. Effects of NGF and BDNF on chemotaxis and matrigel invasion; comparison with basal migratory and invasive capabilities. ${ }^{a}$

\begin{tabular}{|c|c|c|c|c|c|c|c|c|c|}
\hline Cell line & Chemotaxis & $\begin{array}{l}\text { Matrigel } \\
\text { invasion }\end{array}$ & I.I. & $\begin{array}{l}\text { NGF-induced } \\
\text { chemotaxis }\end{array}$ & $\begin{array}{c}\text { NGF-induced } \\
\text { matrigel } \\
\text { invasion }\end{array}$ & I.I. & $\begin{array}{l}\text { BDNF-induced } \\
\text { chemotaxis }\end{array}$ & $\begin{array}{c}\text { BDNF-induced } \\
\text { matrigel } \\
\text { invasion }\end{array}$ & I.I. \\
\hline PC3 & $40 \pm 4$ & $25 \pm 7$ & 0.62 & $\begin{array}{l}81 \pm 7 \\
(2.0)\end{array}$ & $\begin{array}{l}69 \pm 7 \\
(2.4)\end{array}$ & $\begin{array}{l}0.73 \\
(1.2)\end{array}$ & $\begin{array}{l}49 \pm 7 \\
(1.2)\end{array}$ & $\begin{array}{c}35 \pm 47 \\
(1.4)\end{array}$ & $\begin{array}{l}0.71 \\
(1.1)\end{array}$ \\
\hline ALVA31 & $55 \pm 4$ & $32 \pm 5$ & 0.58 & $\begin{array}{l}88 \pm 10 \\
(1.6)\end{array}$ & $\begin{array}{l}74 \pm 6 \\
(2.3)\end{array}$ & $\begin{array}{l}0.84 \\
(1.4)\end{array}$ & $\begin{array}{c}68 \pm 10 \\
(1.2)\end{array}$ & $\begin{array}{l}47 \pm 6 \\
(1.5)\end{array}$ & $\begin{array}{l}0.69 \\
(1.2)\end{array}$ \\
\hline DU145 & $35 \pm 2$ & $20 \pm 4$ & 0.57 & $\begin{array}{c}115 \pm 4 \\
(3.3)\end{array}$ & $\begin{array}{l}98 \pm 4 \\
(4.9)\end{array}$ & $\begin{array}{l}0.85 \\
(1.5)\end{array}$ & $\begin{array}{l}65 \pm 4 \\
(1.9)\end{array}$ & $\begin{array}{l}50 \pm 4 \\
(2.5)\end{array}$ & DU145 \\
\hline $\begin{array}{l}\text { DU14 } 5 \\
\text { pcDNA }\end{array}$ & $32 \pm 4$ & $18 \pm 2$ & 0.56 & $\begin{array}{c}108 \pm 7 \\
(3.4)\end{array}$ & $\begin{array}{r}88 \pm 2 \\
(4.9)\end{array}$ & $\begin{array}{l}0.81 \\
(1.4)\end{array}$ & $\begin{array}{r}64 \pm 7 \\
(2.0)\end{array}$ & $\begin{array}{r}43 \pm 2 \\
(2.4)\end{array}$ & $\begin{array}{l}0.72 \\
(1.4)\end{array}$ \\
\hline PC3 neo & $43 \pm 4$ & $22 \pm 7$ & 0.51 & $\begin{array}{l}77 \pm 7 \\
(1.8)\end{array}$ & $\begin{array}{l}62 \pm 7 \\
(2.8)\end{array}$ & $\begin{array}{l}0.81 \\
(1.6)\end{array}$ & $\begin{array}{c}49 \pm 10 \\
(1.1)\end{array}$ & $\begin{array}{c}38 \pm 47 \\
(1.7)\end{array}$ & $\begin{array}{l}0.77 \\
(1.5)\end{array}$ \\
\hline Mean \pm SD & $41 \pm 9$ & $23 \pm 5$ & $\begin{array}{c}0.57 \\
{[0.04]}\end{array}$ & $93 \pm 17$ & $78 \pm 15$ & $\begin{array}{c}0.81 \\
{[0.05]}\end{array}$ & $59 \pm 9$ & $43 \pm 6$ & $\begin{array}{c}0.73 \\
{[0.04]}\end{array}$ \\
\hline PC3-AR & $19 \pm 4$ & $10 \pm 3$ & 0.53 & $\begin{array}{l}61 \pm 6 \\
(3.2)\end{array}$ & $\begin{array}{l}45 \pm 8 \\
(4.5)\end{array}$ & $\begin{array}{l}0.74 \\
(1.4)\end{array}$ & $\begin{array}{l}69 \pm 7 \\
(1.4)\end{array}$ & $\begin{array}{c}50 \pm 11 \\
(2.0)\end{array}$ & $\begin{array}{l}0.67 \\
(1.2)\end{array}$ \\
\hline DU-AR & $25 \pm 2$ & $6 \pm 4$ & 0.40 & $\begin{array}{l}75 \pm 4 \\
(3.0)\end{array}$ & $\begin{array}{l}38 \pm 4 \\
(6.3)\end{array}$ & $\begin{array}{l}0.51 \\
(1.3)\end{array}$ & $\begin{array}{l}45 \pm 4 \\
(1.8)\end{array}$ & $\begin{array}{l}26 \pm 4 \\
(4.3)\end{array}$ & $\begin{array}{c}0.58 \\
(1.45)\end{array}$ \\
\hline 22rv1 & $32 \pm 4$ & $13 \pm 2$ & 0.40 & $\begin{array}{l}89 \pm 4 \\
(2.8)\end{array}$ & $\begin{array}{l}68 \pm 2 \\
(5.2)\end{array}$ & $\begin{array}{l}0.76 \\
(1.9)\end{array}$ & $\begin{array}{l}55 \pm 4 \\
(1.7)\end{array}$ & $\begin{array}{l}20 \pm 2 \\
(2.3)\end{array}$ & $\begin{array}{l}0.57 \\
(1.4)\end{array}$ \\
\hline ND1 & $35 \pm 4$ & $10 \pm 2$ & 0.28 & $\begin{array}{l}61 \pm 7 \\
(1.7)\end{array}$ & $\begin{array}{l}28 \pm 2 \\
(2.8)\end{array}$ & $\begin{array}{l}0.45 \\
(1.6)\end{array}$ & $\begin{array}{l}41 \pm 7 \\
(1.2)\end{array}$ & $\begin{array}{l}25 \pm 2 \\
(2.5)\end{array}$ & $\begin{array}{l}0.61 \\
(2.2)\end{array}$ \\
\hline LnCaP & $10 \pm 3$ & $3 \pm 2$ & 0.30 & $\begin{array}{l}30 \pm 4 \\
(3.0)\end{array}$ & $\begin{array}{l}11 \pm 2 \\
(3.7)\end{array}$ & $\begin{array}{l}0.33 \\
(1.1)\end{array}$ & $\begin{array}{l}10 \pm 4 \\
(1.0)\end{array}$ & $\begin{array}{l}4 \pm 2 \\
(1.3)\end{array}$ & $\begin{array}{l}0.40 \\
(1.3)\end{array}$ \\
\hline Mean \pm SD & $24 \pm 16$ & $8 \pm 4$ & $\begin{array}{c}0.38 \\
{[0.10]}\end{array}$ & $63 \pm 22$ & $38 \pm 21$ & $\begin{array}{c}0.56 \\
{[0.20]}\end{array}$ & $44 \pm 22$ & $25 \pm 17$ & $\begin{array}{c}0.57 \\
{[0.10]}\end{array}$ \\
\hline & & & & \multicolumn{2}{|c|}{$\begin{array}{c}\text { TrkA/p75 NTR } \\
\text { ligand }\end{array}$} & \multicolumn{4}{|c|}{$\begin{array}{l}\text { TrkB } \\
\text { ligand }\end{array}$} \\
\hline
\end{tabular}

a.I, invasion index. Numbers in parenthesis, fold increase; numbers in brackets, SD.

matrigel invasion was higher but not statistically higher in AR-negative than in AR-positive cells $(p=0.056)$ and with a similar increase of $\sim 2$-fold; iii) the invasion indices were statistically higher in AR-negative than in AR-positive cells ( $p=0.08)$ but with a similar fold increase. In addition, the increment of BDNF-induced invasion index was statistically significant in both AR-negative $(\mathrm{p}<0.001)$ and AR-positive $(\mathrm{p}<0.05)$ cells; and iv) the BDNF-induced cell invasion (considering the invasion indices) was related with TrkB expression with a correlation coefficient of $0.781(\mathrm{p}=0.045)$.

Effects of NT3. In Fig. 3 we show migratory and invasive dose-response effects of NT3 (targeting TrkC) in 22rv1 and PC3 cells. NT3 is able to induce chemotactic responses and matrigel invasion with a maximal effect between 5 and $10 \mathrm{ng} / \mathrm{ml}$. The effect of NT3 $(5 \mathrm{ng} / \mathrm{ml})$ has been compared in all PCa cell lines (Table V). We found the following: i) NT3- induced cell migration was statistically higher in AR-negative than in AR-positive cells $(\mathrm{p}=0.28)$ but with a similar increment of $\sim 10 \%$ with respect to basal; ii) NT3-induced matrigel invasion was statistically higher in AR-negative than in ARpositive cells $(\mathrm{p}=0.010)$ but with a similar fold increase of 1.5; iii) the invasion indices were statistically higher in ARnegative than in AR-positive cells $(\mathrm{p}=0.017)$ but with a similar fold increase of $\sim 1.3$. In addition the increment of NT3-induced invasion index was not statistically significant in AR-negative and AR-positive cells; and iv) the NT3-induced cell invasion (analyzing the invasion indices) was not statistically related with TrkC expression with a correlation coefficient of 0.638 (NS).

Effects of CEP-701. Therefore we tried to verify whether CEP-701, a quinazoline derivative which inhibits Trk activity, was able to reduce both Trk phosphorylation and the invasive 


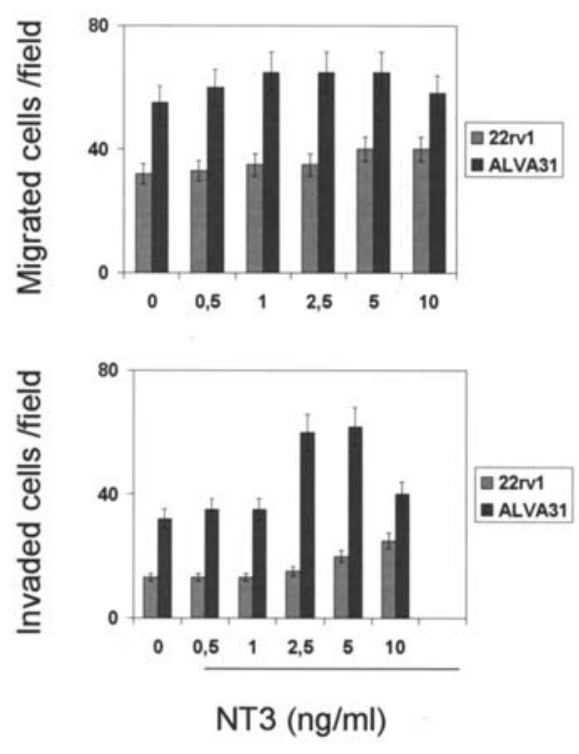

Figure 3. Chemotaxis and chemoinvasion of 22rv1 and DU145 using NT3 as a chemoattracting agent. This is a representative dose-dependent experiment. Each value is the mean of triplicate counts $\pm \mathrm{SE} . \mathrm{P}<0.005$ after $2.5 \mathrm{ng} / \mathrm{ml}$ NT3.

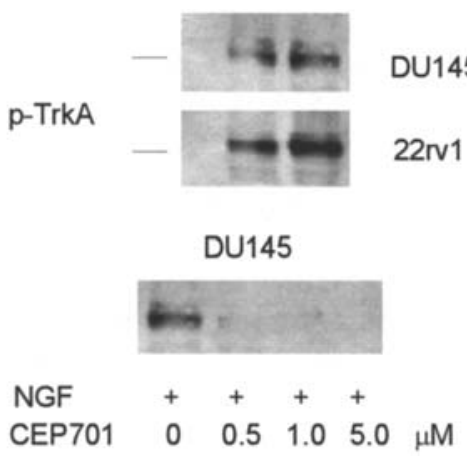

Figure 4. Western blots of DU145 and 22rv1 cell extracts in cells treated with 5-10 $\mathrm{ng} / \mathrm{ml} \mathrm{NGF}$ for $30 \mathrm{~min}$ and with CEP-701 0-5 $\mu \mathrm{M}$ for $15 \mathrm{~min}$ followed by NGF $10 \mathrm{ng} / \mathrm{ml}$ treatment for $30 \mathrm{~min}$. Cell extracts $(40 \mu \mathrm{g})$ were loaded for each lane. Nitrocellulose filters were blotted for an antibody recognized phospho-TrkA.

capability of cells. In Fig. 4 we show that NGF-mediated TrkA phosphorylation is inhibited by CEP-701 in a dosedependent manner in DU145 and 22rv1 cells. Similar results (data not shown) were obtained with other cell lines. BDNFmediated TrkB and NT3-mediated-TrkC phosphorylation were also inhibited by CEP-701 indicating its wide activity on several Trk family members (data not shown). Moreover NGF- and, to a minor extent, BDNF-induced migration and invasiveness were inhibited by Trk receptor tyrosine kinase inhibitor, CEP-701 (data not shown and Fig. 5).

\section{Discussion}

NGF and its receptors, trkA and p75NGFR, are present in the prostate of several species, localized both in epithelial and in stromal cells (32). In the prostate, p75NGFR is progressively lost during tumorigenesis (33-35), and it has been proposed
Table V. Effects of NT3 on chemotaxis and matrigel invasion; comparison with basal migratory and invasive capabilities. ${ }^{a}$

\begin{tabular}{lccc}
\hline Cell line & $\begin{array}{c}\text { NT3-induced } \\
\text { chemotaxis }\end{array}$ & $\begin{array}{c}\text { NT3-induced } \\
\text { matrigel invasion }\end{array}$ & I.I. \\
\hline PC3 & $47 \pm 5$ & $27 \pm 3$ & 0.57 \\
ALVA31 & $(1.2)$ & $(1.1)$ & $(0.9)$ \\
& $60 \pm 2$ & $42 \pm 4$ & 0.70 \\
DU145 & $(1.1)$ & $(1.3)$ & $(1.2)$ \\
& $40 \pm 4$ & $25 \pm 4$ & 0.62 \\
DU145 & $(1.1)$ & $(1.25)$ & $(1.1)$ \\
pcDNA & $35 \pm 2$ & $22 \pm 4$ & 0.63 \\
PC3 neo & $(1.1)$ & $(1.2)$ & $(1.1)$ \\
& $41 \pm 4$ & $32 \pm 5$ & 0.78 \\
Mean \pm SD & $(1.0)$ & $(1.5)$ & $(1.5)$ \\
& $45 \pm 9$ & $30 \pm 8$ & 0.66 \\
PC3-AR & & & {$[0.08]$} \\
& $23 \pm 4$ & $12 \pm 2$ & 0.52 \\
DU-AR & $(1.2)$ & $(1.2)$ & $(0.9)$ \\
& $28 \pm 4$ & $10 \pm 2$ & 0.36 \\
22rv1 & $(1.1)$ & $(1.7)$ & $(0.9)$ \\
& $40 \pm 3$ & $25 \pm 4$ & 0.62 \\
ND1 & $(1.25)$ & $(1.9)$ & $(1.55)$ \\
& $32 \pm 3$ & $15 \pm 4$ & 0.47 \\
LnCaP & $(0.9)$ & $(1.5)$ & $(1.7)$ \\
& $8 \pm 3$ & $4 \pm 4$ & 0.50 \\
Mean \pm SD & $26 \pm 12$ & $(1.3)$ & $(1.7)$ \\
& & $43 \pm 8$ & 0.49 \\
& & & {$[0.09]$}
\end{tabular}

TrkC ligand

a.I., invasion index. Numbers in parenthesis, fold increase; numbers in brackets, SD.

that disappearance of this NGF receptor could represent a marker of malignancy of prostate cancer (34). An imbalance between trkA- and p75NGFR-mediated signals could, thus, be involved or cooperate in the progression of PCa cells (36). In this context, we demonstrated that a low expression of p75 NTR was observed in more invasive PCa cell lines. We have observed that Trk A expression is higher compared to normal and hyperplastic prostate in $\sim 40 \%$ of prostate cancers (unpublished data) and this is in agreement with a series of previous immunohistochemical evaluations mentioned above $(12,37)$. In addition we demonstrated that NTs and primarily NGF are able to induce cell migration and invasion of PCa cell lines and that the increment in cell movement and invasiveness is related to the malignant potential of the cells. In addition cells such as the LNCaP cell line and its cell derivatives which are inable to secrete detectable levels of NT 
A

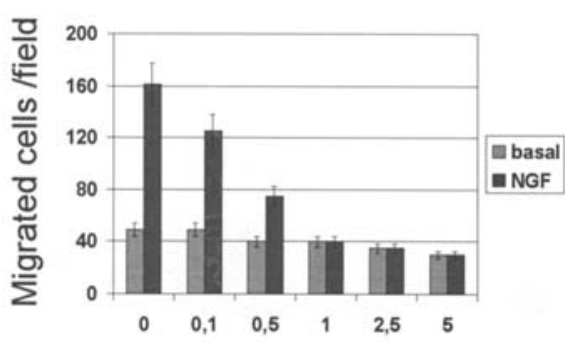

$\mathrm{B}$

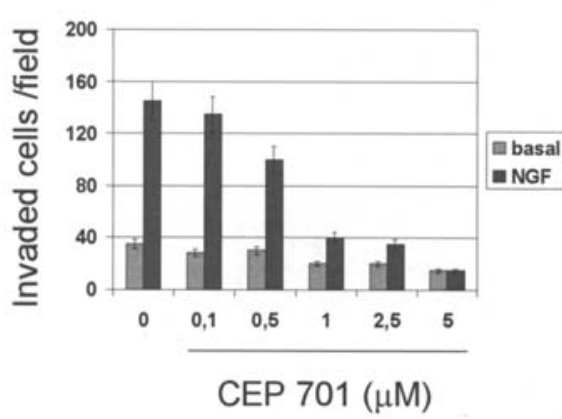

C
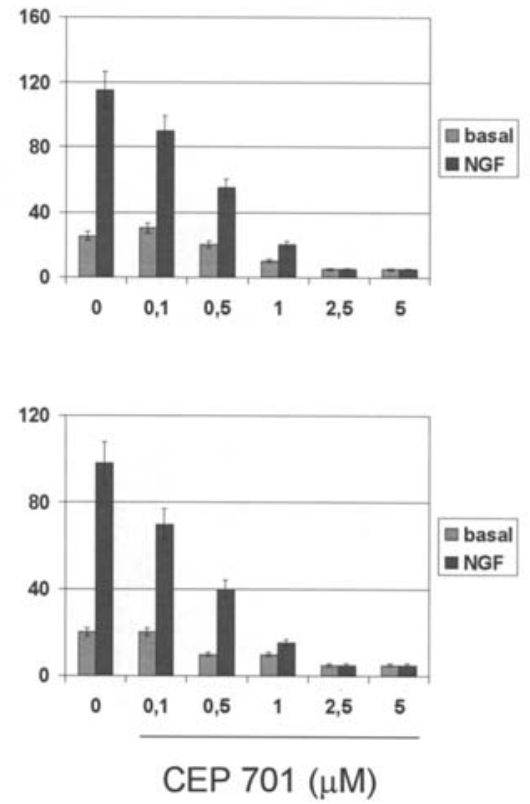

Figure 5. Chemotaxis and chemoinvasion of DU145 (A and B) and 22rv1 (C and D) using $10 \mathrm{ng} / \mathrm{ml}$ NGF as a chemoattracting agent. This is a representative dose-dependent experiment. Each value is the mean of triplicate counts $\pm \mathrm{SE}$. $\mathrm{P}<0.001 \mathrm{after} 2.5 \mathrm{ng} / \mathrm{ml} \mathrm{BDNF}$.

Table VI. $\mathrm{IC}_{50}$ values calculated for CEP-701 in some PCa cell lines.

\begin{tabular}{lccc}
\hline Cell line & $\begin{array}{c}\text { NGF-induced } \\
\text { matrigel } \\
\text { invasion }\end{array}$ & $\begin{array}{c}\text { BDNF-induced } \\
\text { matrigel } \\
\text { invasion }\end{array}$ & $\begin{array}{c}\text { NT3-induced } \\
\text { matrigel } \\
\text { invasion }\end{array}$ \\
\hline PC3 & $0.50 \pm 0.17$ & $0.60 \pm 0.11$ & $0.80 \pm 0.22$ \\
ALVA31 & $0.35 \pm 0.21$ & $0.35 \pm 0.14$ & $0.65 \pm 0.12$ \\
DU145 & $0.25 \pm 0.02$ & $0.38 \pm 0.04$ & $0.88 \pm 0.03$ \\
PC3-AR & $0.32 \pm 0.02$ & $0.52 \pm 0.008$ & $0.87 \pm 0.05$ \\
DU-AR & $0.22 \pm 0.02$ & $0.42 \pm 0.008$ & $0.82 \pm 0.08$ \\
22rv1 & $0.30 \pm 0.05$ & $0.53 \pm 0.08$ & $0.63 \pm 0.02$ \\
ND1 & $0.32 \pm 0.06$ & $0.72 \pm 0.05$ & $>1.0$ \\
LNCaP & $0.64 \pm 0.02$ & $>1.0$ & $>1.0$ \\
& & TrkB & TrkC \\
& TrkA/p75 NTR & ligand & ligand \\
\hline
\end{tabular}

are able to respond to exogenous NT suggesting that the presence of NT receptors is sufficient to start the migratory/ invasive processes in a paracrine fashion. Indeed experimental studies in tissue culture show that carcinoma-associated stromal cells can promote prostatic carcinogenesis and that normal stromal cells may be able to inhibit prostatic carcinogenesis by inducing differentiation and decreasing the proliferation of the epithelium. Although the complex molecular mechanisms through which stroma modulates the epithelial cell phenotype remain to be elucidated, there are several well- characterized signaling pathways, such as those for growth factors and steroid hormones, that are likely to contribute to the modulation of transformed epithelial cells. Although our results demonstrated that low doses of NT including NGF, comparable to levels present in prostate stroma, can modulate tumor migration and invasion to a higher extent in androgeninsensitive when compared to androgen-sensitive cells, it is possible that the interference of TrkA/p75-NGFR balance can be a therapeutic tool to induce cell differentiation and to reduce cell growth through an NGF-mediated re-expression of functionally active ARs. Mechanisms by which prostate cancer cells escape androgen ablation and become independent of the need for androgens are not yet well understood. Therefore, CEP-701, a pan Trk inhibitor, which is able to inhibit the tyrosine kinase activity of all three subtypes of trk receptors via competition at the ATP-binding site, blocks the chemotaxis and the chemoinvasion of all PCa cell lines tested in our experiments suggesting that TrkA triggering may modulate cell movement and cell invasion in prostate cancer. In addition a phase I clinical trial with CEP-701 was well tolerated by patients with advanced malignancy and established the recommended dose level for planned phase II trials (38). In conclusion our data may contribute to the understanding of biological process modifications during the metastatic progression of $\mathrm{PCa}$ and in particular the perineural invasion (whose contribution in the positive margins incidence will be addressed in a future manuscript in preparation) observed in early invasive events of the loco-regional disease, which may be driven by the enhanced neutrophin sensitivity of the tumors, which is instead lost in the advanced stages characterized by distant metastases. Moreover, the results shown in this study have identified a possible therapeutic role for CEP-701, in particular for androgen-resistant, highly invasive human PCa cells. 


\section{References}

1. Di Marco E, Mathor M, Bondanza S, Cutuli N, Marchisio PC, Cancedda $\mathrm{R}$ and De Luca $\mathrm{M}$ : Nerve growth factor binds to normal human keratinocytes through high and low affinity receptors and stimulates their growth by a novel autocrine loop. J Biol Chem 268: 22838-22846, 1993.

2. Djakiew D, Delsite R, Plufg B, Wrathall J, Lynch JH and Onoda M: Regulation of growth by a nerve growth factor-like protein which modulates paracrine interactions between a neoplastic epithelial cell line and stromal cells of the human prostate. Cancer Res 51: 3304-3310, 1991.

3. Otten U, Ehrhard P and Peck R: Nerve growth factor induces growth and differentiation of human B lymphocytes. Proc Natl Acad Sci USA 86: 10059-10063, 1989.

4. Rubin JB and Segal RA: Growth, survival and migration: the Trk to cancer (Review). Cancer Treat Res 115: 1-18, 2003.

5. Donovan MJ, Hempstead B, Huber LJ, Kaplan D, Tsoulfas P, Chao M, Parada L and Schofield D: Identification of the neurotrophin receptors p75 and trk in a series of Wilms' tumors. Am J Pathol 145: 792-801, 1994.

6. Oelmann E, Sreter L, Schuller I, Serve H, Koenigsmann M, Wiedenmann B, Oberberg D, Reufi B, Thiel E and Berdel WE: Nerve growth factor stimulates clonal growth of human lung cancer cell lines and a human glioblastoma cell line expressing high-affinity nerve growth factor binding sites involving tyrosine kinase signaling. Cancer Res 55: 2212-2219, 1995.

7. Miknyoczki SJ, Lang D, Huang L, Klein-Szanto AJP, Dionne CA and Ruggeri BA: Neurotrophin and trk receptors in human pancreatic ductal adenocarcinoma: expression patterns and effects on in vitro invasive behavior. Int J Cancer 81: 417-427, 1999.

8. McGregor LM, McCune BK, Graff JR, McDowell PR, Romans KE, Yancopoulos GD, Ball DW, Baylin SB and Nelkin BD: Role of trk family neurotrophin receptors in medullary thyroid carcinoma development and progression. Proc Natl Acad Sci USA 96: 4540-4545, 2001.

9. Davidson B, Reich R, Lazarovici P, Ann Florenes V, Nielsen S and Nesland JM: Altered expression and activation of the nerve growth factor receptors TrkA and p75 provide the first evidence of tumor progression to effusion in breast carcinoma. Breast Cancer Res Treat 83: 119-128, 2004.

10. Deschryver-Kecskemeti K, Balogh K and Neet K: Nerve growth factor and the concept of neural-epithelial interactions. Arch Pathol Lab Med 111: 833-835, 1987.

11. Satoh F, Mimata H, Nomura T, Fujita Y, Shin T, Sakamoto S, Hamada Y and Nomura Y: Autocrine expression of neurotrophins and their receptors in prostate cancer. Int J Urol 8: S28-S34, 2001.

12. Dionne CA, Camoratto AM, Jani JP, Emerson E, Neff N, Vaught JL, Murakata C, Djakiew D, Lamb J, Bova S, George D and Isaacs JT: Cell cycle-independent death of prostate adenocarcinoma is induced by the trk tyrosine kinase inhibitor CEP-751 (KT6587). Clin Cancer Res 4: 1887-1898, 1998.

13. Miknyoczki SJ, Wan W, Chang H, Dobrzanski P, Ruggeri BA, Dionne CA and Buchkovich K: The neurotrophin-trk receptor axes are critical for the growth and progression of human prostatic carcinoma and pancreatic ductal adenocarcinoma xenografts in nude mice. Clin Cancer Res 8: 1924-1931, 2002.

14. Weeraratna AT, Dalrymple SL, Lamb JC, Denmeade SR, Miknyoczki S, Dionne CA and Isaacs JT: Pan-trk inhibition decreases metastasis and enhances host survival in experimental models as a result of its selective induction of apoptosis of prostate cancer cells. Clin Cancer Res 7: 2237-2245, 2001.

15. Geldof AA, De Kleijn MAT, Rao BR and Newling DWW: Nerve growth factor stimulates in vitro invasive capacity of DU145 human prostatic cancer cells. J Cancer Res Clin Oncol 123: 107-112, 1997.

16. Angelsen A, Sandvik AK, Syversen U, Stridsberg M and Waldum HL: NGF-beta, NE-cells and prostatic cancer cell lines. A study of neuroendocrine expression in the human prostatic cancer cell lines DU-145, PC-3, LNCaP, and TSU-pr1 following stimulation of the nerve growth factor-beta. Scand J Urol Nephrol 32: 7-13, 1998.

17. Djakiew D, Pflug BR, Delsite R, Onoda M, Lynch J, Arand G and Thompson EW: Chemotaxis and chemokinesis of human prostate tumor cell lines in response to human prostate stromal cell secretory proteins containing a nerve growth factor like protein. Cancer Res 53: 1416-1420, 1993.
18. Van Bokhoven A, Varella-Garcia M, Korch C, Johannes WU, Smith EE, Miller HL, Nordeen SK, Miller GJ and Lucia MS: Molecular characterization of human prostate carcinoma cell lines. Prostate 57: 205-225, 2003.

19. Douma S, van Laar T, Zevenhoven J, Meuwissen R, van Garderen E and Peeper DS: Suppression of anoikis and induction of metastasis by the neurotrophic receptor TrkB. Nature 430: 1034-1039, 2004.

20. Sinnappah-Kang ND, Kaiser AJ, Blust BE, Mrak RE and Marchetti D: Heparanase, TrkC and p75NTR: their functional involvement in human medulloblastoma cell invasion. Int $\mathbf{J}$ Oncol 27: 617-626, 2005.

21. George DJ, Dionne CA, Jani J, Angeles T, Murakata C, Lamb J and Isaacs JT: Sustained in vivo regression of Dunning $\mathrm{H}$ rat prostate cancers treated with combinations of androgen ablation and Trk tyrosine kinase inhibitors, CEP-751 (KT-6587) or CEP-701 (KT-5555). Cancer Res 59: 2395-2401, 1999.

22. Narayan P and Dahiya R: Establishment and characterization of a human primary prostatic adenocarcinoma cell line (ND-1). J Urol 148: 1600-1604, 1992.

23. Horoszewicz JS, Leong SS, Chu TM, Wajsman ZL, Friedman M, Papsidero L, Kim U, Chai LS, Kakati S, Arya SK and Sandberg AA: The LNCaP cell line - a new model for studies on human prostatic carcinoma. Prog Clin Biol Res 37: 115-132, 1980 .

24. Tepper CG, Boucher DL, Ryan PE, Ma AH, Xia L, Lee LF, Pretlow TG and Kung HJ: Characterization of a novel androgen receptor mutation in a relapsed CWR22 prostate cancer xenograft and cell line. Cancer Res 62: 6606-6614, 2002.

25. Kaighn ME, Narayan KS, Ohnuki Y, Lechner JF and Jones LW: Establishment and characterization of a human prostatic carcinoma cell line (PC-3). Invest Urol 1: 16-23, 1979.

26. Stone KR, Mickey DD, Wunderli H, Mickey GH and Paulson DF: Isolation of a human prostate carcinoma cell line (DU 145). Int J Cancer 21: 274-281, 1979.

27. Loop SM, Rozanski TA and Ostenson RC: Human primary prostate tumor cell line, ALVA-31: a new model for studying the hormonal regulation of prostate tumor cell growth. Prostate 22: 93-108, 1993

28. Scaccianoce E, Festuccia C, Dondi D, Guerini V, Bologna M, Motta $\mathrm{M}$ and Poletti A: Characterization of prostate cancer DU145 cells expressing the recombinant androgen receptor. Oncol Res 14: 101-112, 2003.

29. Bonaccorsi L, Muratori M, Marchiani S, Forti G and Baldi E: The androgen receptor and prostate cancer invasion. Mol Cell Endocrinol 246: 157-162, 2006.

30. Pettaway CA, Pathak S, Greene G, Ramirez E, Wilson MR, Killion JJ and Fidler IJ: Selection of highly metastatic variants of different human prostatic carcinomas using orthotopic implantation in nude mice. Clin Cancer Res 2: 1627-1636, 1996.

31. Angelucci A, Gravina GL, Rucci N, Festuccia C, Muzi P, Vicentini C, Teti A and Bologna M: Evaluation of metastatic potential in prostate carcinoma: an in vivo model. Int $\mathrm{J}$ Oncol 25: 1713-1720, 2004.

32. Dalal R and Djakiew D: Molecular characterization of neurotrophin expression and the corresponding tropomysin receptor kinases (trks) in epithelial and stromal cells of the human prostate. Mol Cell Endocrinol 134: 15-22, 1997.

33. Graham CW, Lynch JH and Djakiew D: Distribution of nerve growth factor-like protein and nerve growth factor receptor in human benign prostatic hyperplasia and prostatic adenocarcinoma. J Urol 147: 1444-1447, 1992.

34. Krygier S and Djakiew D: The neurotrophin receptor p75NTR is a tumor suppressor in human prostate cancer. Anticancer Res 21A: 3749-3755, 2001.

35. Krygier S and Djakiew D: Neurotrophin receptor p75(NTR) suppresses growth and nerve growth factor-mediated metastasis of human prostate cancer cells. Int J Cancer 98: 1-7, 2002.

36. Pflug B and Djakiew D: Expression of p75NTR in a human prostate epithelial tumor cell line reduces nerve growth factorinduced cell growth by activation of programmed cell death. Mol Carcinog 23: 106-114, 1998.

37. Guate JL, Fernandez N, Lanzas JM, Escaf S and Vega JA: Expression of p75(LNGFR) and Trk neurotrophin receptors in normal and neoplastic human prostate. BJU Int 84: 495-502, 1999.

38. Marshall JL, Kindler H, Deeken J, Bhargava P, Vogelzang NJ, Rizvi N, Luhtala T, Boylan S, Dordal M, Robertson P, Hawkins MJ and Ratain MJ: Phase I trial of orally administered CEP-701, a novel neurotrophin receptor-linked tyrosine kinase inhibitor. Invest New Drugs 23: 31-37, 2005. 